fra en sykdom som rammet nesten hver eneste familie, til å bli forbundet med immigranter, fattige og hjemløse. De siste kapitlene er viet de historiske årsakene til at sykdommen har gått radikalt tilbake i Vesten. Ikke minst understreker forfatterne at å få en effektiv behandling ble en viktig del av arbeiderbevegelsens kamp for sosial rettferdighet.

Boken har en lang rekke interessante perspektiver. Det er dens styrke og svakhet. Den spriker i mange retninger uten noen klar rød tråd, samtidig som den gir mye verdifull innsikt og grunnlag for refleksjon over tuberkulose - som på mange måter har vært, og fortsatt er, menneskehetens største svøpe. Det største problemet er at forfatterne nesten utelukkende tar utgangspunkt i Vesten og knapt nevner at resistent tuberkulose faktisk er på fremmarsj i store deler av verden. Tuberkulosens historie er ikke ferdigskrevet, vi går tvert imot sannsynligvis inn i det viktigste kapitlet.

Dag Gundersen Storla

Infeksjonsmedisinsk seksjon

Lovisenberg diakonale sykehus

\section{Engelsk på ekte vis}

\section{Conrad Keating}

Smoking kills

The revolutionary life of Richard Doll. 495 s, tab, ill. Oxford: Signal Books, 2009. Pris GBP 18 ISBN 978-1-904955-63-0

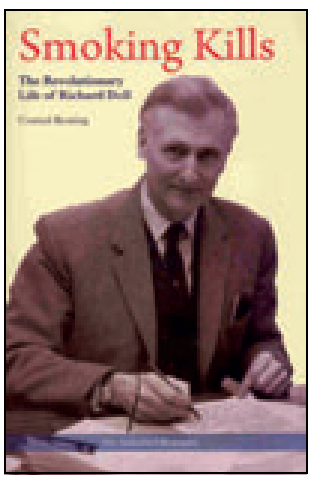

Boken med den krystallklare tittelen Smoking kills er biografien til en dominerende skikkelse i moderne medisinsk forskning (1). Undertittelen The revolutionary life of Richard Doll er tvetydig, men dekkende for Richard Dolls

(1912-2005) revolusjonære og revolusjonerende liv.

Som ung medisinstudent ble Doll, på tross av sin overklassebakgrunn og borgerlige utdanning, fenget av sosialismen. Det var først etter den sovjetiske invasjonen i Ungarn i 1956 at han sa farvel til sin kommunistiske overbevisning. Som andre likesinnede engasjerte han seg sterkt for sosialismen og mot fascismen, og da andre verdenskrig kom, meldte han seg som nyutdannet lege til tjeneste. Ett utfall av krigen var at Doll måtte fjerne en nyre pga. tuberkulose, et annet at krigsinnsatsen forpurret hans kliniske innsats hjemme. Det kan medisinfaget på mange måter være takknemlig for.

\section{Forsker, lærer, sakkyndig}

I 1948 var den registrerte dødeligheten blant menn for første gang høyere for lungekreft enn lungetuberkulose. Det medforte en dreining i forskningen i retning av ikke-infeksiøse, kroniske og potensielt livstruende tilstander og falt sammen med Dolls revolusjonerende karriere.

Richard Doll brukte sitt talent for matematikk og statistikk til å studere lungekreft blant ansatte i asbestindustrien. Deretter spilte han en sentral rolle i den første randomiserte kliniske studien i sitt slag. Det gjaldt bruken av streptomycin i behandlingen av tuberkulose, senere også i kombinasjon med paraaminosalisylsyre (PAS). Men hans livslange innsats var fremfor alt knyttet til kohortstudien av røykevaner og helseutfall blant mannlige bristiske leger, som han ledet fra tidlig på 1950-tallet. Doll deltok aktivt frem til resultatene av 50-årsoppfølgingen forelå året før han døde. Da var bare vel 6000 av de over 30000 opprinnelige deltakerne fortsatt i live, og Doll var en av dem. Dolls egen mentor, Austin Bradford Hill (1897-1991), og hans adept Richard Peto (f. 1943), er begge uløselig knyttet til studien som entydig viser at røyking er årsaken til et stort antall alvorlige sykdommer og utallige tapte leveår.

Dolls navn er også knyttet til senskadene etter radioaktiv eksponering, dvs. etter røntgenbehandling av pasienter med kroniske leddsykdommer, blant overlevende etter Hiroshima-katastrofen og de over 20000 australske veteranene som hadde deltatt i atombombeprøvene i Stillehavet. Det omfattet også aktiviteten rundt kjernekraftverket i Sellafield i Skottland.

Det skjedde en omveltning i Richard Dolls liv da han rundt 1970 forlot London og ble Regius (kongelig) professor i medisin ved universitetet i Oxford. Som den første epidemiolog i stillingen hadde han i starten vansker med å bli akseptert av «the old boys» i klinikken, men under hans ledelse skjedde store endringer i organiseringen av medisinstudiet, inkludert etableringen av det helt nye Green College for medisin. Den offisielle åpningen av Richard Dolls hus i Oxford skjedde få uker etter hans død.

I kraft av sin kompetanse opptrådte Richard Doll regelmessig som ekspertvitne i erstatningssaker som gjaldt påviste $o g$ antatte skader fra tobakksrøyking og radioaktiv stråling. Oftest sto han på saksøkerens side. Med sin akademiske klarhet var han en respektert aktør og fryktet motstander. For Doll var den vitenskapelige sannheten det viktigste, men han agiterte så å si aldri for sitt syn. I stedet lot han fakta tale for seg og overlot fortolkningene og konklusjonen til andre, enten det var rettens formann eller helseministeren.

\section{Nobelkomiteens unnlatelsessynd}

Boken er inndelt etter de tematiske avsnittene i Richard Dolls liv. Den støttes av et omfat- tende kildegrunnlag og er morsom og inspirerende å lese. Leseren får en overveldende innsikt i sosialmedisinens og epidemiologiens historie i engelsk versjon fra 1930-tallet og utover. Et vell av personer og begivenheter omtales, og tidvis må leseren virkelig holde på hatten for å følge med i svingene. Forfatteren beskriver og siterer direkte navngitte personer uten at det virker nærgående, avslørende eller skandaliserende. Fotnoter og anekdoter florerer. De gir ekstra liv til fremstillingen og bidrar til å tegne bildet av Richard Doll som én av mange sentrale skikkelser som deltok i et intelligent, aktivt og konstruktivt samspill til beste for folkehelsen i den britiske velferdsstatens første år.

Mangfoldige millioner personleveår er blitt spart takket være Richard Dolls forskning. Jeg vet at han ble nominert til nobelprisen i medisin flere ganger. Doll kan nokså sikkert beskrives som verdens ledende epidemiolog på 1900-tallet. Når han etter nærmere seks tiårs innsats aldri fikk prisen, er det lite trolig at «De Aderton» vil se i retning dette faget med det første. Det er i så måte deres blinde flekk.

Alle med interesse for klinisk og epidemiologisk forskning vil kunne glede seg over boken om Richard Doll. Det mest spennende er å oppdage at hans tilnærming til problemstillingene fortsatt er høyst aktuell.

\section{Geir W. Jacobsen}

Norges teknisk-naturvitenskapelige universitet

\section{Litteratur}

1. Leira HL. Sir Richard has entered the building.. Tidsskr Nor Lægeforen 2001; 121: 2219.

\section{Med nese for lukt}

Christopher H. Hawkes, Richard L. Doty The neurology of olfaction

244 s, tab, ill. Cambridge: Cambridge University Press, 2009. Pris GBP 45

ISBN 978-0-521-68216-9

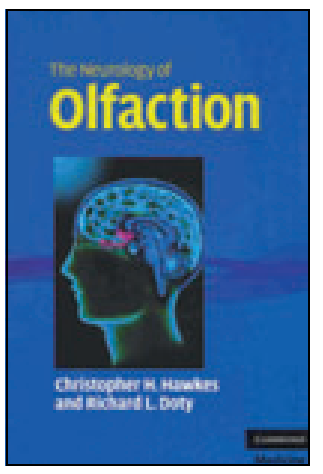

Luktesansen ble utviklet for 550 millioner år siden og har en uhyre kompleks nevroanatomisk organisering som er helt annerledes enn våre øvrige sansesystemers. Det er bl.a. det eneste sansesystemet som kommuniserer

direkte med cerebral cortex uten å gå veien om thalamus. I likhet med den andre av våre to kjemiske sanser, smakssansen, har luktesansen tradisjonelt hatt en noe «annenrangs» posisjon i klinisk medisin, sammenliknet med våre øvrige sanser. Ingen som 